1 Unidade de Endocrinologia do Desenvolvimento, Laboratório de Hormônios e Genética Molecular/ LIM42, Hospital das Clínicas, Faculdade de Medicina da Universidade de São Paulo (HCFMUSP), São Paulo, SP, Brazil

\author{
Correspondence to: \\ Letícia F. G. Silveira \\ Daiane Beneduzzi \\ Av. Dr. Eneas de Carvalho \\ Aguiar, 155, $2^{\circ}$ andar, Bloco 6 \\ 05403-900 - São Paulo, SP, Brazil \\ leticia_gontijo@yahoo.com.br \\ daianebeneduzzi@yahoo.com.br \\ Received on July/31/2012 \\ Accepted on Sept/26/2012
}

\section{Novel mutation in the gonadotropin-releasing hormone receptor (GNRHR) gene in a patient with normosmic isolated hypogonadotropic hypogonadism}

\author{
Nova mutação no receptor do hormônio liberador \\ de gonadotrofinas (GNRHR) em um paciente com \\ hipogonadismo hipogonadotrófico isolado normósmico
}

Daiane Beneduzzi', Ericka B. Trarbach', Ana Claudia Latronico', Berenice Bilharinho de Mendonca', Letícia F. G. Silveira'

\section{SUMMARY}

We report a novel GNRHR mutation in a male with normosmic isolated hypogonadotropic hypogonadism $(\mathrm{n} \mid \mathrm{HH})$. The coding region of the GNRHR gene was amplified and sequenced. Three variants p.[Asn10Lys;GIn11Lys]; [Tyr283His] were identified in the GNRHR coding region in a male with sporadic complete $\mathrm{nIHH}$. The three variants were absent in the controls (130 normal adults). Familial segregation showed that the previously described p.Asn10Lys and p.GIn11Lys are in the same allele, in compound heterozygozity with the novel variant p.Tyr283His. The p.[Asn10Lys;GIn11Lys] are known inactivating mutations. The p.Tyr283His affects a well-conserved residue, and in silico analysis suggested it is a deleterious variant. We describe a novel GNRHR mutation in a male with $\mathrm{nlHH}$. Absence of the mutation in the control group, conservation among species, in silico analysis, and familial segregation suggest that p.Tyr283His, which was identified in compound heterozygozity with the p.[Asn10Lys;GIn11Lys] variants, is an inactivating mutation. Arq Bras Endocrinol Metab. 2012;56(8):540-4

\section{SUMÁRIO}

Relatamos uma nova mutação no gene GNRHR em um homem com hipogonadismo hipogonadotrófico isolado normósmico (HHIn). A região codificadora do gene GNRHR foi amplificada e sequenciada. Três variantes p.[Asn10Lys;Gln11 Lys]; [Tyr283His] foram identificadas no GNRHR em um homem com HHIn esporádico. As três variantes estavam ausentes no grupo controle (130 adultos normais). A segregação familiar mostrou que as variantes previamente descritas p.[Asn10Lys;Gln11Lys] se localizavam no mesmo alelo, em heterozigose composta com a nova variante p.Tyr283His. As mutações p.[Asn10Lys;Gln11Lys] são sabidamente inativadoras. A variante p.Tyr283His afeta um resíduo bem conservado, e a análise in silico sugeriu que essa é uma mutação deletéria. Descrevemos uma mutação inédita no gene GNRHR em um paciente com HHIn nIHH. A ausência da variante no grupo controle, a conservação entre as espécies, a análise in silico e a segregação familiar sugerem que a p.Tyr283His é uma mutação inativadora, identificada em heterozigose composta com as mutações p.[Asn10Lys;GIn11 Lys]. Arq Bras Endocrinol Metab. 2012;56(8):540-4

\section{INTRODUCTION}

$\mathrm{C}$ ongenital isolated hypogonadotropic hypogona$\bigcup_{\text {dism }}(\mathrm{IHH})$ is characterized by partial or com- plete lack of pubertal development, secondary to deficient GnRH-induced gonadotropin secretion (1). Diagnosis is based on the presence of low levels of sex 
steroids associated with low or inappropriately normal LH and FSH serum levels, with no anatomical lesion in the hypothalamic-pituitary tract, and no other pituitary hormone deficiencies (2).

Normosmic IHH $(\mathrm{nIHH})$ is a rare and genetically heterogeneous condition, which occurs most commonly in the sporadic form or, less frequently, inherited as an autosomic recessive trait (3). GnRH receptor inactivating mutations were the first recognized monogenic causes of this condition (4). Up to 22 inactivating mutations of human GnRHR have now been described, distributed along the whole receptor, in the transmembrane domains, and extracellular or intracellular loops, with no hotspot. These mutations impair $\mathrm{GnRH}$ signaling by means of the loss of receptor expression, ligand binding, G-protein coupling, and/or abnormal intracellular trafficking of the receptor (5). After GNRHR mutations, defects in a number of genes have been associated with the pathogenesis of $\mathrm{nIHH}$, although GNRHR is still the most commonly affected gene in this condition (6).

In the present study, we describe a sporadic case of complete nIHH associated with a novel mutation of the GNRHR gene.

\section{CASE REPORT}

A 16-year-old male came to medical attention complaining of lack of pubertal development. He was born at term from a non-consanguineous couple, following an uncomplicated pregnancy, with a normal male external genitalia and topic testes. He denied similar cases in the family. At physical examination, he had absent facial and body hair, eunuchoid habitus (height, $174.2 \mathrm{~cm}$, arm span, $175 \mathrm{~cm}$ ), weight, $73.2 \mathrm{~kg}$, pubic hair tanner stage III, pre-pubertal testes $(1.5 \times 1.0 \mathrm{~cm}$ and $1.4 \times 1.0 \mathrm{~cm}$ ), and micropenis (penis length 7.0 $\mathrm{x} 2.0 \mathrm{~cm}, \mathrm{Z}-4.2$ ). He had a normal sense of smell, as confirmed by a normal Smell Identification TestTM (UPSTI, Philadelphia, PA), and no other associated features. Basal hormonal evaluation revealed low serum testosterone $(20 \mathrm{ng} / \mathrm{dL})$, LH $(0.17 \mathrm{IU} / \mathrm{L})$, and FSH $(0.7 \mathrm{IU} / \mathrm{L})$ levels. Other tests of anterior pituitary function were normal, as was a subsequent magnetic resonance imaging scan of the hypothalamus-pituitary region. His bone age was 13 years. He was started on low IM doses of testosterone cypionate (200 mg/month) for 6 months. After withdrawal of testosterone therapy his hormonal levels returned to pre-pubertal levels, and by the age of 18 he still did not have spontaneous pubertal development, confirming the diagnosis of normosmic IHH. The patient was then started on full replacement dose of IM testosterone cypionate (200 mg every 3 weeks).

\section{MATERIAL AND METHOD}

The protocol was approved by the Ethical Committee of Hospital das Clínicas da FMUSP (0713/2011). Written informed consent was obtained from the patient and his parents. The control population consisted of 130 Brazilian adults with normal pubertal development.

\section{Hormone assays}

Serum LH and FSH concentrations were determined by immunofluorometric assays (IFMA, AutoDELFIA hLH Spec and AutoDELFIA hFSH, Wallac Oy, Turku, Finland). Sensitivity was set at $0.1 \mathrm{IU} / \mathrm{L}$ for $\mathrm{LH}$, and 1.0 IU/L for FSH. Serum testosterone concentrations were measured by commercial solid-phase fluoroimmunoassay (FIA) (AutoDELFIA Testosterone, PerkinElmer, Turku, Finland), with sensitivity of $14 \mathrm{ng} / \mathrm{dL}(0.6 \mathrm{nmol} /$ liter $)$ for testosterone. The interassay coefficient of variation was $5 \%$ or less for all assays.

\section{Genetic analysis}

Genomic DNA from the proband and his father was extracted from peripheral leukocytes. The three exons of the GNRHR gene (Accession no. NM_000406.2) were amplified by polymerase chain reaction (PCR) using specific, previously described intronic primers pairs (7). Amplification reactions were performed in a final volume of $25 \mu \mathrm{L}$ containing $10 \mathrm{pmol}$ of each primer, $150 \mathrm{ng}$ template DNA, $200 \mu \mathrm{mol} / \mathrm{L} \mathrm{dNTPs}$, 2.5 U Taq polymerase, $2.5 \mu \mathrm{L} 10 \mathrm{x}$ buffer containing $1.5 \mathrm{mM} \mathrm{MgCl}_{2}$, and carried out for 35 cycles: denaturation at $94^{\circ} \mathrm{C}$ for $30 \mathrm{sec}$, annealing at $55-57^{\circ} \mathrm{C}$ for $30 \mathrm{sec}$, extension at $72^{\circ} \mathrm{C}$ for $1 \mathrm{~min}$, followed by a final extension for $10 \mathrm{~min}$ at $72^{\circ} \mathrm{C}$. All PCR products were separated on $1 \%$ agarose gel electrophoresis, and automatically sequenced using the ABI Prism TM Big Dye terminator Kit (Perkin-Elmer, Foster City, CA, USA) in an ABI Prism Genetic Analyzer 3100 automatic DNA sequencer (Perkin- Elmer, Foster City, CA, USA). 


\section{In silico analysis}

Mutation Taster (http://www.mutationtaster.org/), PolyPhen-2 (http://genetics.bwh.harvard.edu/ pph2/), and SIFT - Sorting Intolerant from Tolerant Human Protein (http://sift.jcvi.org/www/ SIFT_enst_submit.html) software were used to predict the putative impact of an amino acid substitution on structure and protein function. These tools are essentially based on sequence information, structural information, or both, and on the premise that protein conservation is correlated with protein function (8-10).

\section{RESULTS}

Sequencing of the GNRHR coding region revealed three variants: p.[Asn10Lys;Gln1 1Lys]; [Tyr283His]. In one allele, a thymine was substituted by adenine at nucleotide position 30 , and a cytosine was substituted by adenine at position 31 in exon 1 , resulting in a two amino acid substitutions, lysine for asparagine and lysine for glutamine, p.Asnl0Lys and p.Glnl 1Lys, respectively, in the $\mathrm{N}$-terminal extracellular domain. These variants were previously described (rs104893843 and rs142842994) $(7,11)$. On the other allele, a novel variant was identified, in which thymine was substituted by cytosine at nucleotide position 847 in exon 3, resulting in tyrosine for histidine substitution (p.Tyr283His) in the seventh transmembrane domain of the GnRH receptor (Figure 1A). Familial segregation showed that the unaffected father of the propositus was only heterozygous for p.[Asn10Lys;Glnl1Lys] mutations, confirming that these variants segregate together in the same allele.

The novel p.Tyr283His variant was absent in the control population of 130 healthy Brazilian adults. In addition, thymine at position 283 of GnRHR is a highly conserved residue among the species, as demonstrated on figure $1 \mathrm{~B}$.

To investigate how this variant could interfere in GnRHR function, in silico analysis of the p.Tyr283His substitution in the GNRHR protein sequence was submitted to three different bioinformatics tools that examine functional effects of single nucleotide variants in humans (SIFT, Poliphen, and Mutation Taster). The p.Tyr283His was considered to be damaging by SIFT software, probably damaging (score 2.310 ) by Polyphen, and disease-causing by Mutation Taster.
A

c. 30T >A ; 31C >A p.(Asn10Lys;Gln11Lys)

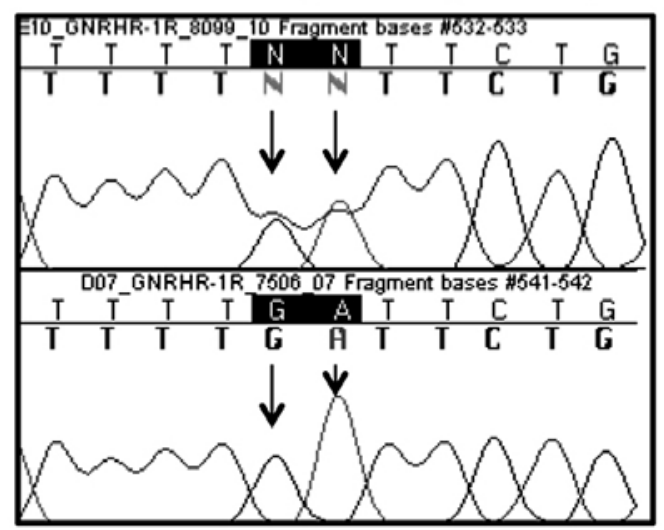

Wild type

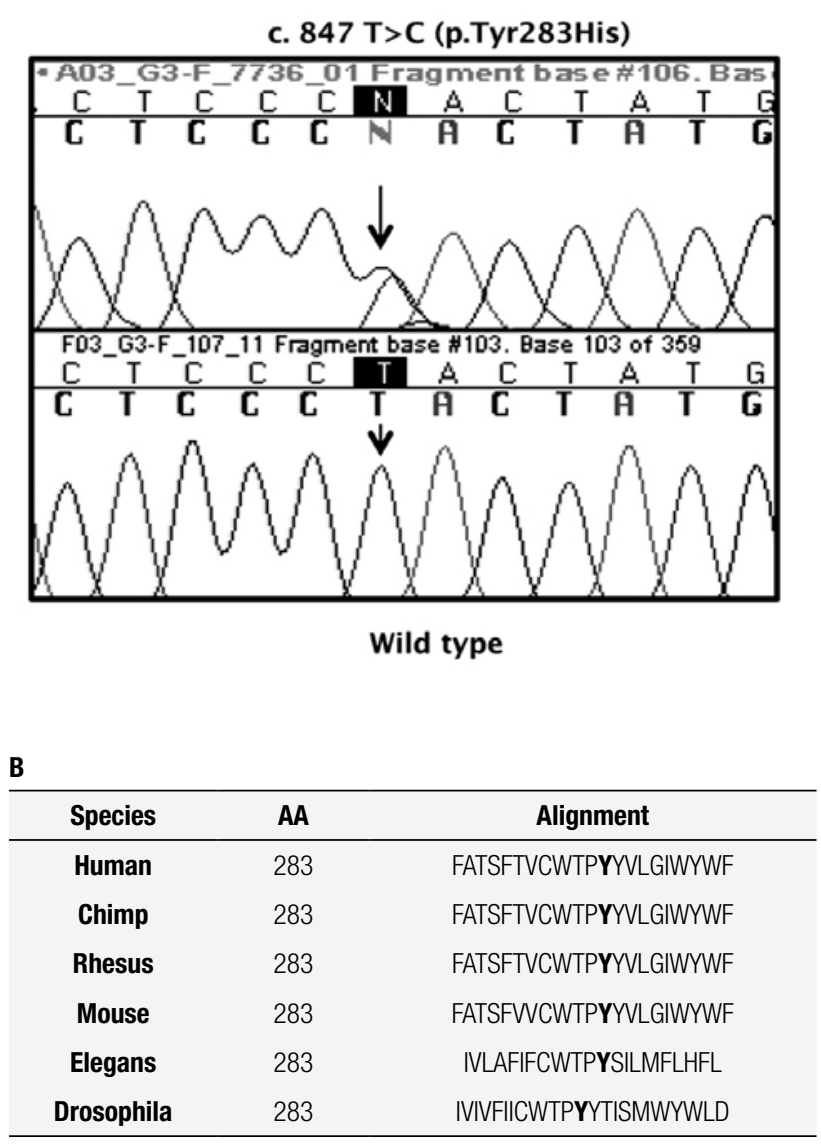

Figure 1. A. Automatic DNA sequencing of the GNRHR gene, showing the heterozygous mutations (p.[Asn10Lys;Gln11Lys] and p.Tyr283His) identified in the male proband with $\mathrm{nHH}$; B. Amino acid sequence alignment of the GNRHR among species; p.Tyr283His is indicated in red.

\section{DISCUSSION}

In this study, we report a patient who presented lack of pubertal development and pre-pubertal levels of serum testosterone, $\mathrm{LH}$, and FSH at age 16. The hypothesis 
of constitutional delay of growth and puberty could not be initially discharged, but was unlikely, considering that the patient did not have short stature, and there was no history of pubertal delay in the family. Nevertheless, diagnosis of complete normosmic IHH could only be confirmed after lack of spontaneous pubertal development, even after short term testosterone therapeutic trial, at 18 years of age.

Sequencing of the GNRHR coding sequence revealed three variants: p.[Asnl0Lys;Glnl lLys]; [Tyr283His]. The p.Asnl0Lys and p.GlnllLys mutations were previously described $(7,11)$. Meysing and cols. (11) reported a case of a normosmic female subject with congenital idiopathic hypogonadotropic hypogonadism, who harbored the p.Asn10Lys, p.Glnl1Lys in the same allele, while a distinct mutation (p.P320L) was identified in the other allele. In vitro functional studies of the p.[Asn 10Lys; Gln11Lys] mutations resulted in reduced ligand binding and impaired intracellular signal transduction capacity (11).

In the present study, familial segregation was performed to investigate the hypothesis that p.Asnl0Lys and p.GlnllLys might be inherited together. The father's DNA was analyzed and revealed that he also carried the p.Asnl0Lys and p.GinllLys mutations in the heterozygous state, and it was concluded that theses variants were inherited together in the same allele. The father had completely normal pubertal development confirming that p.[Asnl0Lys; Glnl1Lys] in the heterozygous state are not sufficient for the phenotype of pubertal delay. Unfortunately, the mother's DNA was not available for study, but we can infer that the p.Tyr283His was either a de novo mutation or it was inherited from the mother.

This is the third time these two mutations p.[Asn 10Lys; Gln11Lys] are described together $(7,11)$. This finding may, in principle, be ascribed to a founder effect. However a second explanation is the existence of a hotspot region involving these two codons.

The p.Tyr283His is a novel variant. Although functional studies are still needed, it is very likely that this is a loss-of-function mutation. The p.Tyr283His was absent in the control group, and the affected tyrosine is a well-conserved residue across the species. In addition, in silico analysis performed on three different current bioinformatics tools is highly suggestive of a deleterious variant. SIFT software predicts the functional importance of the amino acid substitutions based on the alignment of orthologous and/or paralogous protein sequences; in this software, p.Tyr283His was considered damaging. PolyPhen software predicts the functional effect of amino acid changes by considering evolutionary conservation, physicochemical properties, and proximity of the substitution to predicted functional domains and/or structural features. In Polyphen, the scores are designated as probably damaging (> 2.00), possibly damaging $(1.50-1.99)$, potentially damaging $(1.25-1.49)$, borderline $(1.00-$ $1.24)$, or benign $(0.00-0.99)$ (12). On Polyphen, the p.Tyr283His was predicted to be probably damaging with a score of 2.310. Finally, MutationTaster employs a Bayes classifier to predict disease potential of an alteration. The Bayes classifier is fed with the outcome of all tests and features of the alterations, and calculates probabilities for the alteration to be either a disease mutation or a harmless polymorphism. For this prediction, frequencies of all single features for known disease mutations/polymorphisms were studied in a large training set composed of $>40,000$ known disease mutations and $>500,000$ polymorphisms. Mutation Taster software predicted that this variant was disease-causing, with possible changes in protein features.

In summary, we describe a male with nIHH harboring a novel p.Tyr283His GNRHR mutation identified in compound heterozygozity with the p.[Asn 10Lys;Gln11Lys] variants. Familial segregation analysis was essential to elucidate that the p.Asn 10Lys and p.GlnllLys were on the same allele, confirming that biallelic defects are necessary for loss-of-function of the receptor. Although functional studies are still needed, many factors such as absence of the p.Tyr283His variant in the control group, familial segregation, conservation across species, and in silico analysis that was highly suggestive of p.Tyr283His as an inactivating GNRHR mutation.

This study was supported by Fundação de Amparo à Pesquisa do Estado de São Paulo (Fapesp) 2011/15530-0.

Disclosure: no potential conflict of interest relevant to this article was reported.

\section{REFERENCES}

1. Silveira LF, Trarbach EB, Latronico AC. Genetics basis for $\mathrm{GnRH}$ dependent pubertal disorders in humans. Mol Cell Endocrinol. 2010;324(1-2):30-8.

2. Seminara SB, Oliveira LM, Beranova M, Hayes FJ, Crowley WF Jr. Genetics of hypogonadotropic hypogonadism. J Endocrinol Invest. 2000;23(9):560-5.

3. Quinton R, Duke VM, Robertson A, Kirk JM, Matfin G, de Zoysa $\mathrm{PA}$, et al. Idiopathic gonadotrophin deficiency: genetic questions 
addressed through phenotypic characterization. Clin Endocrinol (Oxf). 2001;55(2):163-74.

4. de Roux N, Young J, Misrahi M, Genet R, Chanson P, Schaison G, et al. A family with hypogonadotropic hypogonadism and mutations in the gonadotropin-releasing hormone receptor. N Engl J Med. 1997;337(22):1597-602.

5. Bianco SD, Kaiser UB. The genetic and molecular basis of idiopathic hypogonadotropic hypogonadism. Nat Rev Endocrinol. 2009;5(10):569-76.

6. Beate K, Joseph N, Nicolas de R, Wolfram K. Genetics of isolated hypogonadotropic hypogonadism: role of $\mathrm{GnRH}$ receptor and other genes. Int J Endocrinol. 2012;2012:147893.

7. Costa EM, Bedecarrats GY, Mendonca BB, Arnhold IJ, Kaiser UB, Latronico AC. Two novel mutations in the gonadotropin-releasing hormone receptor gene in Brazilian patients with hypogonadotropic hypogonadism and normal olfaction. J Clin Endocrinol Metab. 2001;86(6):2680-6.
8. Adzhubei IA, Schmidt S, Peshkin L, Ramensky VE, Gerasimova A, Bork $P$, et al. A method and server for predicting damaging missense mutations. Nat Methods. 2010;7(4):248-9.

9. Schwarz JM, Rodelsperger C, Schuelke M, Seelow D. MutationTaster evaluates disease-causing potential of sequence alterations. Nat Methods. 2010;7(8):575-6.

10. Ng PC, Henikoff S. Predicting deleterious amino acid substitutions. Genome Res. 2001;11(5):863-74.

11. Meysing AU, Kanasaki H, Bedecarrats GY, Acierno JS Jr, Conn PM, Martin KA, et al. GNRHR mutations in a woman with idiopathic hypogonadotropic hypogonadism highlight the differential sensitivity of luteinizing hormone and follicle-stimulating hormone to gonadotropin-releasing hormone. J Clin Endocrinol Metab. 2004;89(7):3189-98.

12. XiT, Jones IM, Mohrenweiser HW. Many amino acid substitution variants identified in DNA repair genes during human population screenings are predicted to impact protein function. Genomics. 2004;83(6):970-9. 